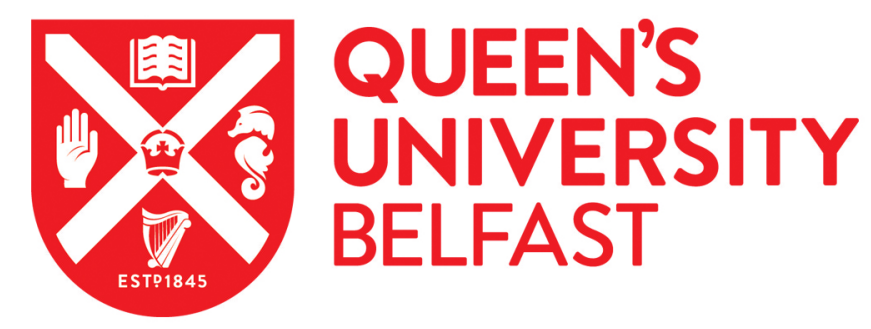

\title{
Characterization of ionic liquid cytotoxicity mechanisms in human keratinocytes compared with conventional biocides
}

McLaughlin, M., Gilea, M. A., Earle, M. J., Seddon, K. R., Gilmore, B. F., \& Kelly, S. A. (2021). Characterization of ionic liquid cytotoxicity mechanisms in human keratinocytes compared with conventional biocides. Chemosphere, 270, [129432]. https://doi.org/10.1016/j.chemosphere.2020.129432

\section{Published in:}

Chemosphere

\section{Document Version:}

Peer reviewed version

Queen's University Belfast - Research Portal:

Link to publication record in Queen's University Belfast Research Portal

\section{Publisher rights}

Copyright 2021 Elsevier.

This manuscript is distributed under a Creative Commons Attribution-NonCommercial-NoDerivs License

(https://creativecommons.org/licenses/by-nc-nd/4.0/), which permits distribution and reproduction for non-commercial purposes, provided the author and source are cited.

\section{General rights}

Copyright for the publications made accessible via the Queen's University Belfast Research Portal is retained by the author(s) and / or other copyright owners and it is a condition of accessing these publications that users recognise and abide by the legal requirements associated with these rights.

Take down policy

The Research Portal is Queen's institutional repository that provides access to Queen's research output. Every effort has been made to ensure that content in the Research Portal does not infringe any person's rights, or applicable UK laws. If you discover content in the Research Portal that you believe breaches copyright or violates any law, please contact openaccess@qub.ac.uk. 
1 Characterization of ionic liquid cytotoxicity mechanisms in human keratinocytes compared with conventional biocides

3 Martin McLaughlin ${ }^{a, c}$, Manuela A. Gilea ${ }^{b}$, Martyn J. Earle ${ }^{b}$, Kenneth R. Seddon ${ }^{b}$,

4 Brendan F. Gilmore, Stephen A. Kelly*a

5 'School of Pharmacy, Queens University Belfast, Medical Biology Centre, 97 Lisburn Road, 6 Belfast, BT9 7BL, UK.

$7{ }^{\text {b}}$ The QUILL Research Centre, School of Chemistry, Queen's University of Belfast, Belfast, 8 BT9 5AG, UK, http://quill.qub.ac.uk/

$9 \quad$ Institute for Cancer Research, 123 Old Brompton Road, London, SW7 3RP, UK

$10 *$ Corresponding author, stephen.kelly@qub.ac.uk

Keywords

13 Apoptosis; Cytotoxicity; Ionic liquids; Keratinocyte; Necrosis; Toxicity.

15 Abstract

16 The ability to chemically modify ionic liquids (ILs) has led to an expansion in interest 17 in their use in a diversity of applications, not least as antimicrobials and biocides. 18 Relatively little is known about cytotoxicity mechanisms of ILs in comparison to 19 other biocides currently in widespread use, as well as their practical significance for 20 the ecological environment and human health. Using NCTC 2544 and HaCat human

21 keratinocyte cells, this study aimed to characterize cytotoxicity rates and mechanisms 22 of a range of ILs. Using both lactate dehydrogenase (LDH) and 3-(4,5- 
23 dimethylthiazol-2-yl)-2,5-diphenyltetrazolium bromide (MTT) based cytotoxicity

24 assays, it was confirmed that at biocide-relevant concentrations, ILs with longer alkyl

25 chains exhibited greater biocidal activity than those with shorter alkyl chains, with

26 comparable activity to the commonly used biocides chlorhexidine, benzalkonium

27 chloride and cetylpyridinium chloride, at relevant in-use biocide concentrations.

28 Mode of cell death, measured using fluorescence-activated cell sorting (FACS) and

29 caspase $3 / 7$ activity, determined necrosis to be the primary cytotoxic mechanism at

30 higher concentrations of the biocides stated above, and with ILs [ $\left.\mathrm{C}_{14} \mathrm{MIM}\right] \mathrm{Cl}$ and

31 [ $\mathrm{C}_{14}$ quin]Br, with apoptosis observed at borderline necrotic concentrations. Perhaps

32 most interestingly, modification of anion had a significant effect on cytotoxicity. The

33 use of $\mathrm{N}\left[\mathrm{SO}_{2} \mathrm{CF}_{3}\right]$ as an anion to $\left[\mathrm{C}_{16} \mathrm{MIM}\right]$ attenuated cytotoxicity 10 -fold in

34 comparison to other anions, suggesting cytotoxicity may also be a tuneable property

35 when using ILs as biocides. 
The capacity to modify the chemical, physical and biological properties of ionic liquids (ILs), through independent modification of their constituent cations and anions, has led to an expanding interest in their use as task specific solvents in a diversity of applications, ranging from synthesis, catalysis and extraction (Berthod et al., 2018; de Melo et al., 2020; Ferlin et al., 2013), through to bioremediation, topical drug delivery and antimicrobial applications. Ionic liquids have been at the forefront in the emerging search for environmentally friendly chemical compounds to replace volatile organic compounds in conventional industrial processes. The ability to modify inherent structural components of the constituent ions permits almost limitless possibilities for tuning these property sets aimed towards improving existing use, or tailoring their use to new and emerging applications.

Unsurprisingly, given the potential range of ILs available, it is now widely accepted that it is no longer feasible to universally label them as 'green' solvents, given the biological toxicity attributable to ILs. Indeed, studies on the potential for collateral toxicity linked to their widespread application have centred around contamination of the aquatic environment, including toxicity to bacteria responsible for biodegradation and damage to cellular morphology of plants and wildlife, as well as bioaccumulation in marine trophic chains (Couling et al., 2006; Liu et al., 2015; Nędzi et al., 2013; Piotrowska et al., 2018; Pretti et al., 2006; Samorì et al., 2007; Sintra et al., 2017; Wells and Coombe, 2006). However, the ability of environmental bacteria to biodegrade certain ILs has been described (Sydow et al., 2018; Thamke et al., 2019), and may therefore mitigate the risks associated with ecotoxicity resulting from accidental environmental exposures. Furthermore, the literature has heralded the potential of ILs as antimicrobial agents (Pernak et al., 2004, 2003; Yu et al., 2016). 
Other studies have highlighted the ability of ILs used in this study, namely 1-alkyl-3methylimidazolium and 1-alkylquinolinium ILs, to effectively eradicate biofilms of clinically relevant pathogens (Busetti et al., 2010; Carson et al., 2009; Pendleton and Gilmore, 2015; Venkata Nancharaiah et al., 2012). Herein exists a division between alternate fields in IL research, one which attempts to ameliorate potential toxicity and another which seeks to harness toxicity as a desirable, tuneable property in the creation of a new designer biocidal compounds. The future potential of widespread consumer use of ILs as biocides (for example as disinfectants, preservatives, and antiseptics) raises the largely unaddressed issue of the potential for toxicity at 'in-use' concentrations to the user; with respiratory, digestive and skin related contact the most likely points of direct exposure. The inherent characteristic of low vapour pressure of ILs removes inhalation as a significant risk of exposure in day to day applications. This leaves topical (skin) exposure as the predominant concern were ILs to be expanded for consumer use.

The skin is a critical target organ in environmental exposure, with numerous studies utilising skin keratinocyte cell lines to identify toxicity, irritation and carcinogenesis. These include the effect of heavy metal ions (Holmes et al., 2020, 2016; Orlowski et al., 2016), surfactants and pharmaceuticals (Abruzzo et al., 2017; Choi et al., 2018; Kim et al., 2019; Sugita et al., 2017), as well as antimicrobial agents (Kim et al., 2008; Lam et al., 2020; Pulingam et al., 2020) and wound sensor materials (Bhushan et al., 2019). In addition, the human keratinocyte cells lines NCTC 2544 and HaCat have previously been used to evaluate ultra-short antimicrobial peptides (Pasupuleti et al., 2009). As keratinocytes represent the major cell type in the human epidermis this in vitro model has been identified as a useful screening tool (Wilhelm et al., 2001). 
Alongside appropriate test systems is the need for appropriate comparative control compounds. The gold standards in the field of biocides for some time has been chlorhexidine (CHX) and the quaternary ammonium compound benzalkonium chloride (BC). The effect of CHX on epidermal necrosis has been studied (Faria et al., 2007), as well as its effect on the expression of apoptotic and cellular stress proteins HSP70, Bcl-2 and GRP78 (Faria et al., 2007), cytoskeletal organisation (Faria et al., 2009; Giannelli et al., 2008) and mitochondrial function (Giannelli et al., 2008; Negrelo Newton et al., 2004). Benzalkonium chloride has been investigated for the ability to induce death, either by apoptosis or necrosis (Brasnu et al., 2008), cause corneal toxicity (Dart, 2003), and has been found to cause a reduction in myosin light chain phosphorylation linked to ATP leakage (Geerling et al., 2001).

We have previously reported 3-(4,5-dimethylthiazol-2-yl)-2,5-diphenyltetrazolium bromide (MTT) based cytotoxicity assays (McLaughlin et al., 2011), and IL degradation by bacterial flora of the marine environment (Megaw et al., 2013). In this study we have expanded our characterization of imidazolium and quinolinium based ILs to cytotoxicity in NCTC 2544 and HaCat human keratinocytes at relevant biocidal concentrations, based on established antimicrobial activity of these compounds. Herein we describe a cytotoxic mode of death which is primarily necrotic, however, apoptosis is observed for ILs which are not rapidly cidal, indicating a mechanisms of cell death which is dependent on alkyl chain length and rate of kill. This study characterizes the cytotoxicity profile and mechanism of a number of ILs at relevant biocidal concentrations against human keratinocytes, an important step in the assessment the safety of ILs for use in biocidal applications. These data are compared to the rate and mechanisms of cytotoxicty of a range of biocides currently in widespread use. 
112 2. Materials and Methods

\section{2.1. Cell Culture Conditions}

114 The human skin keratinocyte cell lines NCTC 2544 and HaCat were used in this

115 study. NCTC 2544 cells were originally obtained from the Interlab Cell Line

116 Collection (Genoa, Italy). Cells were cultured in RPMI 1640 medium (Invitrogen,

117 Paisley, UK), supplemented with $2 \mathrm{mM} L$-glutamine and $1 \%$ penicillin/streptomycin

118 (both from Invitrogen) and 10\% foetal bovine serum from (Biosera, East Sussex,

119 UK). HaCat cells were purchased from Cell Line Service (Eppelheim, Germany).

120 Cells were cultured in DMEM containing $4.5 \mathrm{~g} / \mathrm{L} D$-glucose from Invitrogen,

121 supplemented with $2 \mathrm{mM}$ L-glutamine, foetal bovine serum and $1 \%$

122 penicillin/streptomycin. Cells were grown at $37^{\circ} \mathrm{C}$ and $5 \% \mathrm{CO}_{2}$ with cells subcultured

123 at 80-90\% confluency. Cell monolayers were rinsed with PBS and treated with

124 trypsin-EDTA (Invitrogen) to detach cells before re-suspension in fresh media.

\subsection{Antimicrobial Compounds}

126 The antimicrobial compounds BC, CHX and cetylpyridinium chloride (CPyr), and the

127 anionic surfactant SDS were purchased from Sigma (Poole, UK). Ionic liquids were

128 synthesised and characterized in house as previously described, for both 1-alkyl-3-

129 methylimmidazolium chloride (Carson et al., 2009) and 1-alkylquinolinium bromide

130 ionic liquids (Busetti et al., 2010).

131 For 1-alkyl-3-methylimmidazolium chloride ionic liquids, a mixture of distilled

132 (vacuum distilled from $\mathrm{CaH}_{2}$ suspension) 1-methylimidazole (1.00 mol) and either 1-

133 chlorooctane or 1-chlorotetradecane (1.05 mol) (used as supplied from Sigma- 
134 Aldrich) was heated with an oil bath at $100{ }^{\circ} \mathrm{C}$ in a one-neck round-bottom flask (500

$135 \mathrm{~cm}^{3}$ ) equipped with a stir bar and reflux condenser, under an inert dinitrogen

136 atmosphere. The end of the reaction was confirmed by testing for the presence of

137 unreacted 1-methylimidazole, by adding a few drops of the reaction mixture to a

138 solution of copper(II) sulfate in water. The development of a blue coloration indicates

139 the reaction is not complete and should be heated for longer. After three days and a

140 negative 1-methylimidazole test, the reaction was connected to a high vacuum pump

141 (at $1 \mathrm{mBar}$ ) and heated for $4 \mathrm{~h}$ at $100{ }^{\circ} \mathrm{C}$ (for $\left[\mathrm{C}_{8} \mathrm{MIM}\right] \mathrm{Cl}$ ) to distil out unreacted 1-

142 chloralkane, or recrystallised from boiling ethyl ethanoate (for [ $\left.\mathrm{C}_{14} \mathrm{MIM}\right] \mathrm{Cl}$ ). For each

143 compound, purity was found to be $98-99 \%$ by ${ }^{1} \mathrm{H}$ NMR spectroscopy. All salts were

144 solid at room temperature, with melting points determined using DSC.

145 For 1-alkylquinolinium bromide ionic liquids, A mixture of quinoline $(0.100 \mathrm{~mol})$ and

146 a slight excess $(0.105 \mathrm{~mol})$ of either 1-bromoctane or 1-brometetradecanewas heated

147 for $3 \mathrm{~d}$ at $80{ }^{\circ} \mathrm{C}$ under dinitrogen. When the reaction was completed (verified by

$148{ }^{1}$ HNMR spectroscopy), the solid was obtained and purified via recrystallisation from

149 boiling toluene/ethyl ethanoate mixtures. This mixture was then cooled at $-15^{\circ} \mathrm{C}$,

150 filtered under vacuum, washed with cold toluene (ca. $50 \mathrm{~cm}^{3}$ ) and dried under

151 vacuum. This recrystallisation process was repeated twice. The compound was then

152 dried in a vacuum oven overnight at $70{ }^{\circ} \mathrm{C}$. For each compound in the series, purity

153 was found to be $98-99 \%$ by ${ }^{1} \mathrm{H}$ NMR spectroscopy. ${ }^{1} \mathrm{H}$ and ${ }^{13} \mathrm{C}$ NMR data revealed

154 no organic impurities. All salts were solid at room temperature, with melting points

155 determined using DSC. 


\subsection{MTT Cytotoxicity Assay}

159 MTT cytotoxicity assays were set up as described previously (McLaughlin et al.,

160 2011). NCTC 2544 and HaCat cells were plated in the absence of

161 penicillin/streptomycin in their respective growth medium as previously outlined.

162 After cell counting, cell lines were seeded at a concentration of $7.5 \times 10^{3}$ cells per well

163 in 96-well plates and left to adhere and recover for $24 \mathrm{~h}$. After $24 \mathrm{~h}$, media was

164 removed and replaced with fresh media containing different concentrations of the

165 compounds outlined in Section 2.2. (a $\log 10$ dilution series in the range $1 \mathrm{mM}$ to

$1661 \times 10^{-8} \mathrm{mM}$ was used). All compounds were initially dissolved in dimethyl sulfoxide

167 (DMSO) with heating at $37^{\circ} \mathrm{C}$ to aid dissolution where required. These stocks were

168 diluted in culture media resulting in a final compound concentration of $1 \mathrm{mM}$ with a

169 final DMSO concentration no higher that $0.5 \%$. Compound-free DMSO controls

170 were included to determine any toxicity related to solvent. Cells were exposed to each

171 concentration of each compound at time points $15 \mathrm{~min}$ and $24 \mathrm{~h}$. After the allocated

172 exposure time had elapsed, media was removed and replaced with fresh media

173 containing $24 \mu \mathrm{M}$ of MTT (Sigma, Poole, UK). Cells were incubated for $2 \mathrm{~h}$ at $37^{\circ} \mathrm{C}$,

$1745 \% \mathrm{CO}_{2}$ after which culture media was removed and any insoluble formazan crystals

175 dissolved using $200 \mu \mathrm{L}$ DMSO per well. Absorption values per well at $570 \mathrm{~nm}$ were

176 measured using a Biotek EL808 spectrophotometer (Labtech, East Sussex, UK).

177 Three independent replicates were carried out for each experiment and percentage cell

178 viability was calculated relative to untreated control.

179 2.4. Lactate Dehydrogenase Assay

180 Leakage of cytoplasmic contents was measured using the in vitro Toxicology Assay

181 Kit, Lactate Dehydrogenase (LDH) based (Sigma), as per manufacturer's instructions. 
182 Briefly, HaCat cells were plated at a concentration of $12.5 \times 10^{3}$ per well in 96 -well

183 plates. After $24 \mathrm{~h}$ cells were treated with different concentrations of biocides or ILs

184 under study in the range $1 \times 10^{0}$ to $1 \times 10^{-4} \mathrm{mM}$. Following incubation for either

$18515 \mathrm{~min}$ or $4 \mathrm{~h}$, plates were centrifuged at $2000 \mathrm{rpm}$ for $4 \mathrm{~min}$ and half the media was

186 removed for LDH analysis. LDH assay mixture was added as recommended by the

187 manufacturer and incubated in the dark for $20 \mathrm{~min}$. Percentage LDH release was

188 calculated by subtraction of background $690 \mathrm{~nm}$ measurement from $490 \mathrm{~nm}$

189 measurement. Untreated cells were used as a control for $0 \%$ compound-induced LDH

190 release and triton $\mathrm{X}-100$ (Sigma) as $100 \%$ release.

\subsection{Flow Cytometry}

192 Apoptosis and necrosis were discriminated by use of annexin V FITC coupled 193 antibody (BD Pharmingen, Oxford, UK), and propidium iodide (Sigma). HaCat cells

194 were plated in 6 well plates at $1 \times 10^{5}$ cells per well and allowed to rest for $24 \mathrm{~h}$. Cells

195 were then exposed to increasing concentrations of each compound under study for

$19624 \mathrm{~h}$. Culture media for each well was collected, cells were washed with PBS, and

197 trypsin-EDTA was used to detach cells. Detached cells, PBS wash and culture 198 supernatant were all combined upon collection. Apoptotic and necrotic cells were 199 pelleted by centrifugation at $2000 \mathrm{rpm}$ for $5 \mathrm{~min}$ after which the cell pellet was 200 resuspended in binding buffer at a final concentration of $10 \mathrm{mM}$ HEPES, $150 \mathrm{mM}$ $201 \mathrm{NaCl}, 5 \mathrm{mM} \mathrm{KCl}, 1 \mathrm{mM} \mathrm{MgCl} 2$, and $18 \mathrm{mM} \mathrm{CaCl}_{2}(\mathrm{pH}$ 7.4). Annexin $\mathrm{V}$ and 202 propidium iodide were mixed with the cell suspension and incubated at room 203 temperature in the dark for $15 \mathrm{~min}$. A minimum of $10^{4}$ events were acquired using a 204 FACS Canto II (BD Biosciences, Oxford, UK). Acquisition, gating and analysis were 205 performed with FACSDiva software (BD Biosciences). 


\subsection{Caspase Activity}

207 Activation of caspase 3 and 7 was assessed using the ApoTox-Glo apoptosis toxicity 208 assay, as per the manufacturer's instructions (Promega, Southampton, UK). Cells were plated at a concentration of $10 \times 10^{3}$ per well in opaque 96-well plates and

210 allowed to rest for $24 \mathrm{~h}$. Cells were treated with sub-necrotic concentrations of 211 biocides or ILs. After a $24 \mathrm{~h}$ incubation, Caspase-Glo 3/7 reagent was added in a one212 to-one ratio to media, mixed for $30 \mathrm{~s}$ on an orbital shaker and incubated for $30 \mathrm{~min}$ 213 before luminescence measurement on a MicroLumat Plus (EG\&G Berthold).

\section{$214 \quad$ 2.7. Western Blot}

215 HaCat cells were plated at a concentration of $3.5 \times 10^{5}$ cells per well in 6 -well plates 216 and left for $24 \mathrm{~h}$. Media was removed, cells were washed in PBS and exposed to 217 media containing different concentrations of biocides or ILs for $24 \mathrm{~h}$. Cells were 218 washed with PBS and lysed on ice in buffer containing $50 \mathrm{mM}$ Tris-HCl, $20 \mathrm{mM}$ 219 EDTA and 1\% nonidet P-40 for 15 minutes. Samples were centrifuged for 15 min at $22014,500 \mathrm{rpm}$ and the supernatant retained. Equal loading of protein samples on SDS221 PAGE was determined by bicinchoninic acid (BCA) assay (Thermo Scientific Pierce, 222 Leicestershire, UK). Whole cell lysates were separated on reduced 4-12\% Bis-Tris 223 NuPAGE gels using NuPAGE MOPS running buffer (Invitrogen). After blotting to 224 PVDF membrane (GE Healthcare, Buckinghamshire, UK), blotted membranes were 225 blocked with 5\% non-fat dry milk in PBS for $1 \mathrm{~h}$ and probed for GRP78 with mouse $226 \alpha$-KDEL (Stressgen, British Columbia, Canada), mouse $\alpha$ - $\gamma$-tubulin (Sigma) and 227 HRP-conjugated goat $\alpha$-mouse secondary (Jackson Immunoresearch, PA, USA). 228 Antibody binding was detected using immobilon western substrate (Millipore, UK) according to the manufacturer's instructions. 


\subsection{Statistical analysis}

231 Statistical analysis was performed using GraphPad Prism software, using either two232 tailed t-tests or one-way ANOVA followed by Tukey's multiple comparisons post233 test.

\section{Results}

\subsection{Cell viability measured by MTT assay}

237 In order to assess the toxicity of 1-alkyl-3-methyimmidazolium chloride $\left(\left[\mathrm{C}_{\mathrm{n}} \mathrm{MIM}\right] \mathrm{Cl}\right)$ 238 and 1-alkylquinolinium bromide ([C $\mathrm{C}$ quin] $] \mathrm{Br})$, a cytotoxicity screen was carried out in 239 two human keratinocyte cell lines. NCTC 2544 and HaCat cell lines have been 240 extensively utilised in the study of compounds pertinent to cutaneous toxicity. 241 Alongside $\left[\mathrm{C}_{\mathrm{n}} \mathrm{MIM}\right] \mathrm{Cl}$ and $\left[\mathrm{C}_{\mathrm{n}}\right.$ quin $] \mathrm{Br}$, the commonly employed biocides $\mathrm{CHX}, \mathrm{BC}$ 242 and CPyr were studied for contextual comparison, along with the $\mathrm{C}_{12}$ alkyl chain 243 containing anionic surfactant, sodium dedecylsulphate (SDS). Cytotoxicity values at a

244 range of concentrations for both $15 \mathrm{~min}$ and $24 \mathrm{~h}$ are shown in Figure 1. Calculated 245 half-maximal effective concentration $\left(\mathrm{EC}_{50}\right)$ values are shown in Table 1.


247 toxic compounds, with an $\mathrm{EC}_{50}$ value calculated to be greater than $1 \mathrm{mM}$, were the $248 \mathrm{C}_{8}$-containing compounds $\left[\mathrm{C}_{8} \mathrm{MIM}\right] \mathrm{Cl}$ and $\left[\mathrm{C}_{8}\right.$ quin $] \mathrm{Br}$. The most toxic group of 249 compounds, with an $\mathrm{EC}_{50}$ value of approximately $0.03-0.07 \mathrm{mM}$, were the common 250 biocides $\mathrm{CHX}, \mathrm{BC}$ and $\mathrm{CPyr}$, as well as the $\mathrm{C}_{14}$ alkyl chain ILs [ $\left.\mathrm{C}_{14} \mathrm{MIM}\right] \mathrm{Cl}$ and 251 [ $\left.\mathrm{C}_{14 q u i n}\right] \mathrm{Br}$. This clustering was conserved at $24 \mathrm{~h}$ also. While $\left[\mathrm{C}_{8} \mathrm{MIM}\right] \mathrm{Cl}$ and $252\left[\mathrm{C}_{8}\right.$ quin $] \mathrm{Br}$ were still the least toxic of the biocides tested, there was a minor 
difference, with $\left[\mathrm{C}_{8} \mathrm{MIM}\right] \mathrm{Cl}$ 3-fold less toxic than [ $\mathrm{C}_{8}$ quin] $\mathrm{Br}$ at 0.255 and $0.086 \mathrm{mM}$

254 EC50 values respectively. $\mathrm{CHX}$ was the next most toxic at $0.012 \mathrm{mM}$, with $\mathrm{BC}, \mathrm{CPyr}$ 255 and $\left[\mathrm{C}_{14} \mathrm{MIM}\right] \mathrm{Cl}$ and $\left[\mathrm{C}_{14}\right.$ quin $] \mathrm{Br}$ approximately similar, with $\mathrm{EC}_{50}$ values falling 256 between 0.002 and $0.004 \mathrm{mM}$.

257 When the same $15 \mathrm{~min}$ and 24 time points were repeated in HaCat cells a number of 258 variations were observed. At $15 \mathrm{~min}, \mathrm{C}_{8}$ alkyl chain containing compounds were still 259 the least toxic with $\mathrm{EC}_{50}$ values of $>1 \mathrm{mM}$. CHX was observed to be more toxic in 260 HaCat cells at 15 min, associating more closely with BC, CPyr and the $\mathrm{C}_{14}$ ILs with 261 EC50 values clustered between approximately 0.05 and $0.03 \mathrm{mM}$. The pattern of 262 toxicity at $24 \mathrm{~h}$ in HaCat cells was similar to that observed in NCTC 2544 cells. At 263 specific concentrations at $24 \mathrm{~h}$ in Figure 1, toxicity to HaCat cells was marginally 264 greater for $\left[\mathrm{C}_{8} \mathrm{MIM}\right] \mathrm{Cl},\left[\mathrm{C}_{14}\right.$ quin $] \mathrm{Br}$ and $[\mathrm{C} 14$ quin] $] \mathrm{Br}$ over that observed in $\mathrm{NCTC}$ 2652544 cells.

\subsection{Cytolysis and LDH Release}

267 We sought to identify the ability of ILs and biocides to induce necrosis using 268 cytolysis assays over very short contact time periods of 15 min when compared to $4 \mathrm{~h}$

269 (Figure 2). Chlorhexidine induced the greatest LDH release, with $20 \%$ of total release 270 occurring at $15 \mathrm{~min}$ for $0.1 \mathrm{mM}$ and $71 \%$ at $15 \mathrm{~min}$ with $1 \mathrm{mM} .4 \mathrm{~h}$ exposure resulted 271 in total $\mathrm{LDH}$ release at both 0.1 and $1 \mathrm{mM}$ concentrations. $\mathrm{BC},\left[\mathrm{C}_{14} \mathrm{MIM}\right] \mathrm{Cl}$ and $272\left[\mathrm{C}_{14}\right.$ quin $] \mathrm{Br}$ exhibited a similar pattern of $\mathrm{LDH}$ release, with negligible release at $27315 \mathrm{~min}$ for $0.1 \mathrm{mM}$, rising to $70-90 \%$ of total release at $15 \mathrm{~min}$ exposure at $1 \mathrm{mM}$. $274 \mathrm{LDH}$ release at $4 \mathrm{~h}$ was total at both 0.1 and $1 \mathrm{mM}$, the same as for $\mathrm{CHX}$. [C $8 \mathrm{MIM}] \mathrm{Cl}$ 275 and [C8quin]Br exhibited no LDH release at 15 min at any tested concentration. Only 
$2761 \mathrm{mM}$ [C8quin]Br induced $\mathrm{LDH}$ release at $4 \mathrm{~h}$ with $35 \%$ of total release, no release

277 for [C8MIM]Cl was observed at any tested concentration at $4 \mathrm{~h}$.

\subsection{Cytotoxicity of anion pairs with $\left[\mathrm{C}_{16} \mathrm{MIM}\right]$ cation}

Research in our group has identified $\left[\mathrm{C}_{14-16} \mathrm{MIM}\right]$ as a lead structure of potent antibacterial and antibiofilm activity (Carson et al., 2009). In order to enhance the biocidal activity, a number of anions have been tested in order to assess their contribution to improving antimicrobial activity. This has led to the identification of $\mathrm{AgCl}_{2}$ anion conferring increased broad spectrum antimicrobial activity against Gram negative bacteria such as P. aeruginosa PAO1 (Gilmore et al., 2013). To fully assess the effect on cytotoxity of various anions, $\mathrm{AgCl}_{2}$ and other anions were tested in HaCat cells at 24 h (Figure 3) with corresponding EC50 values shown in Table 2. Inclusion of a cuprate anion $\left(\mathrm{CuCl}_{4}\right)$ or silver-containing anions $\left(\mathrm{AgCl}_{2}\right.$ or $\left.\mathrm{AgBr}_{2}\right)$ resulted in a small increase in toxicity when compared to the chloride anion. The inclusion of cuprate anion as $\mathrm{CuBr}_{2}$ had similar toxicity to the chloride anion at all concentrations. A significant decrease in toxicity over the chloride anion was observed for $\left[\mathrm{C}_{16} \mathrm{MIM}\right] \mathrm{N}\left[\mathrm{SO}_{2} \mathrm{CF}_{3}\right]$ at a number of concentrations, most notably at $0.01 \mathrm{mM}$ (Figure 3) $(\mathrm{p}<0.0001)$.

\subsection{Analysis of apoptotic and necrotic cell death}

Flow cytometry using propidium iodide and annexin V staining were carried out to identify apoptotic and necrotic cells following IL exposure. Loss of membrane integrity and entry of propidium iodide signified necrotic cells, whereas propidium iodide negative but annexin $\mathrm{V}$ positive cells indicated apoptosis. The ubiquitous antimicrobial compounds $\mathrm{CHX}$ and $\mathrm{BC}$ were tested as comparative controls. $\mathrm{CHX}$ and $\mathrm{BC}$ were observed to induce a large necrotic population of PI positive, annexin $\mathrm{V}$ 
negative cells, at both $1 \mathrm{mM}$ and $0.1 \mathrm{mM}$. Approximately $10 \%$ of the cell population

301 were necrotic at $0.01 \mathrm{mM}$ after $24 \mathrm{~h}$ exposure. Interestingly, the necrosis observed at

$3020.01 \mathrm{mM}$ coincided with a small but statistically significant level of apoptosis.

303 Treatment-free controls exhibited low levels of apoptosis at $1.4 \%$ of the total cell

304 population, $0.01 \mathrm{mM}$ CHX resulted in an increase in apoptotic cells to $4.0 \%$, and $3050.01 \mathrm{mM} \mathrm{BC}$ resulted in a rise to $4.4 \%$ after $24 \mathrm{~h}$ exposure.

306 Of the ILs tested, the results partitioned into two groups. As for Figure 1, the data in

307 Figure 4A shows that toxicity is linked to alkyl chain length. The $\mathrm{C}_{14}$ alkyl chain 308 bearing compounds $\left[\mathrm{C}_{14} \mathrm{MIM}\right] \mathrm{Cl}$ and $\left[\mathrm{C}_{14}\right.$ quin] $\mathrm{Br}$, exhibited a profile similar to $\mathrm{CHX}$ 309 and $\mathrm{BC}$ over the concentration range tested. This was one of total necrosis at 0.1 and $3101 \mathrm{mM}$, with lower levels of necrosis observed at $0.01 \mathrm{mM}$, which also coincided with 311 increased apoptosis. This increase in apoptosis was 6.5 and $5.6 \%$ for $\left[\mathrm{C}_{14} \mathrm{MIM}\right] \mathrm{Cl}$ and 312 [ $\mathrm{C}_{14}$ quin] $\mathrm{Br}$ respectively, compared to $1.4 \%$ in controls.

313 The $\mathrm{C}_{8}$ alkyl chain group comprising $\left[\mathrm{C}_{8} \mathrm{MIM}\right] \mathrm{Cl}$ and $\left[\mathrm{C}_{8}\right.$ quin] $\mathrm{Br}$ were toxic at $1 \mathrm{mM}$ 314 only, similar to the findings by MTT assay in Figure 1. [C $8 \mathrm{MIM}] \mathrm{Cl}$ was marginally 315 less toxic overall as measured by fluorescence-activated cell sorting (FACS), not 316 bringing about complete toxicity at $1 \mathrm{mM}$. At this concentration, decreased necrosis 317 and increased apoptosis $(10.3 \%)$ was observed, similar to the trend observed at lower 318 doses of the $\mathrm{C}_{14}$ compounds. This was not observed for [C 8 quin]Br, which 319 transitioned from little observable toxicity at $0.1 \mathrm{mM}$ to total necrosis at $1 \mathrm{mM}$.

320 To confirm the increased apoptosis by an alternative method, activation of caspase $3 / 7$ 321 was measured at 0.001 and $0.01 \mathrm{mM}$ for $\mathrm{CHX}, \mathrm{BC},\left[\mathrm{C}_{8} \mathrm{MIM}\right] \mathrm{Cl}$ and $\left[\mathrm{C}_{14} \mathrm{MIM}\right] \mathrm{Cl}$ 322 (Figure 4B). Statistically increased levels of apoptosis were observed in three conditions, $0.01 \mathrm{mM} \mathrm{CHX}, 0.01 \mathrm{mM} \mathrm{BC}$ and $0.01 \mathrm{mM}\left[\mathrm{C}_{14} \mathrm{MIM}\right] \mathrm{Cl}$. Basal caspase 
324 3/7 activity was recorded at 1100 Relative Luminescence Units (RLU), this increased 325 to 1700 RLU with $0.01 \mathrm{mM} \mathrm{CHX,} 3700$ RLU with $0.01 \mathrm{mM} \mathrm{BC}$ and 6400 RLU with $3260.01 \mathrm{mM}\left[\mathrm{C}_{14} \mathrm{MIM}\right] \mathrm{Cl}$. The pattern of increase in apoptosis closely corresponded to 327 that observed for annexin V (Figure 4A) with induction shown at identical 328 concentrations, the greatest induction observed for $\left[\mathrm{C}_{14} \mathrm{MIM}\right] \mathrm{Cl}$ and the least for 329 CHX.

\subsection{Endoplasmic Reticulum stress as measured by GRP78 expression}

331 GRP78 is the major regulator and response chaperone of the endoplasmic reticulum 332 (ER) related to the induction of ER stress and the unfolded protein response (Kim et 333 al., 2006). It has previously been shown that CHX induces an upregulation of GRP78 334 in murine L929 fibroblast cells (Faria et al., 2009). We sought to investigate this 335 possibility in HaCat cells for both biocides and 1-alkylmethylimmidazolium chloride 336 ILs. In western blots (Figure 5A) with quantification of three independent 337 experiments by densitometry, corrected for fluctuations in $\gamma$-tubulin levels (Figure 338 5B), no significant changes in GRP78 expression was observed in HaCat cells for any 339 compound at $24 \mathrm{~h}$.

\section{4. Discussion}

342 Ionic liquid toxicity studies published to date predominantly focus on 343 contact/exposure times of $24 \mathrm{~h}$ or greater, a duration far in excess of that expected for 344 biocide applications, where short contact times and rapid toxicity are necessary. The 345 data presented focuses on short-term exposure, conditions which are more likely to 346 correspond to small to medium scale biocidal applications, compared to large scale 
industrial use. The biocides CHX (Giannelli et al., 2008) and BC (Brasnu et al., 2008)

348 have been investigated at 15 min time points, and right down to 1 min exposures.

349 Previous studies have used criteria based on $\mathrm{EC}_{50}$ values to judge the toxicity of ionic 350 liquids, based on the UFT Merck Ionic Liquids Biological Effects Database (Fatemi 351 and Izadiyan, 2011; Radošević et al., 2013). Based on the leukaemia cell line IPC-81, 352 ILs are classified as possessing either very high $\left(\mathrm{EC}_{50}<0.001 \mathrm{mM}\right)$, high $(0.001<$ $\left.353 \mathrm{EC}_{50}<0.1 \mathrm{mM}\right)$, moderate $\left(0.1<\mathrm{EC}_{50}<5 \mathrm{mM}\right)$, or low $\left(\mathrm{EC}_{50}>5 \mathrm{mM}\right)$ toxicity. Using 354 the $\mathrm{EC}_{50}$ values for HaCat cells following 15 min exposure, $\mathrm{CHX}, \mathrm{BC}, \mathrm{CPyr}$, $355\left[\mathrm{C}_{14} \mathrm{Qn}\right] \mathrm{Cl}$, and $\left[\mathrm{C}_{14} \mathrm{MIM}\right] \mathrm{Cl}$ would be considered to have high toxicity, with 356 moderate toxicities observed for SDS, $\left[\mathrm{C}_{8} \mathrm{Qn}\right] \mathrm{Br}$, and $\left[\mathrm{C}_{8} \mathrm{MIM}\right] \mathrm{Cl}$.

357 The toxicity profiles of CHX, CPyr and BC match closely those of both $\left[\mathrm{C}_{14} \mathrm{MIM}\right] \mathrm{Cl}$ 358 and [ $\mathrm{C}_{14}$ quin]Br (Figure 1), and can justifiably be grouped as inducing a similar 359 cytotoxic impact. Comparison of $\left[\mathrm{C}_{8} \mathrm{MIM}\right] \mathrm{Cl}$ and $\left[\mathrm{C}_{8}\right.$ quin] $\mathrm{Br}$ to $\mathrm{SDS}$ reveals both $\mathrm{C}_{8}$ 360 alkyl chain containing ILs exhibit a moderate toxicity, similar to anionic surfactants 361 present in numerous consumer products over $15 \mathrm{~min}$ exposures. The effect of alkyl 362 chain length on toxicity is well established (Cvjetko Bubalo et al., 2014; Diaz et al., 363 2018; Li et al., 2012; Radošević et al., 2013), and this study shows how IL alkyl chain 364 length correlates to commonly used biocides and surfactants.

365 LDH release (Figure 2), a measure of cytoplasmic leakage, corresponded closely to 366 that measured by MTT. This exhibited a time delay where initial high LDH release 367 closely corresponded to downstream loss in cell viability in Figure 1. The degree of 368 correlation is indicative of necrotic release of cellular contents, including LDH, as the 369 major component of downstream cell death. It is also notable that treatment groups 370 showing significantly increased levels of death via apoptosis (Figure 4), exhibited 
371 little or no LDH release, further indicating the correlation between LDH release and 372 necrotic cell death.

373 MTT cytotoxicity of varying anions is interesting in two respects. While silver has 374 been shown to possess enhanced antimicrobial properties against Gram negative 375 bacteria such as $P$. aeruginosa (Gilmore et al., 2013; Poulter et al., 2009; Yuan et al., 376 2017), this does not translate into a comparable increase in cytotoxicity. Additionally, 377 use of $\mathrm{N}\left[\mathrm{SO}_{2} \mathrm{CF}_{3}\right]$ actually attenuates the cytotoxicity of $\left[\mathrm{C}_{16} \mathrm{MIM}\right]$ ten-fold compared 378 to all other anions tested, with the exception of chloride (4-fold). This may indicate 379 the ability to "tune" for increased biocidal activity without a corresponding increase 380 in mammalian cell toxicity.

381 The identification of apoptosis and necrosis through FACS analysis of annexin V and 382 propidium iodide has previously been used in the study of CHX (Faria et al., 2009) 383 and BC (Brasnu et al., 2008). The results observed for HaCat cells (Figure 4) 384 correspond closely to that reported for CHX and BC in the literature with L929 385 fibroblasts and Chang/IOBA-NHC cells respectively. In this study and others for 386 CHX and BC, necrosis was observed at higher concentrations and apoptosis at 387 borderline necrotic concentrations, though HaCat cells appear less sensitive overall 388 than Chang or IOBA-NHC cells (Brasnu et al., 2008). This pattern was also observed 389 for both $\left[\mathrm{C}_{14} \mathrm{MIM}\right] \mathrm{Cl}$ and $\left[\mathrm{C}_{14}\right.$ quin] $\mathrm{Br}$. $\left[\mathrm{C}_{8} \mathrm{MIM}\right] \mathrm{Cl}$ conformed to the pattern of an 390 apoptotic population at sub-necrotic levels, however this was not observed with 391 [C8quin]Br. Apoptosis, as measured by both FACS and caspase 3/7 activation, 392 corresponded closely. A number of recent studies have used a similar approach to 393 examine cell death mode of other cell types following treatment with imidazolium394 based ILs. Apoptosis was shown to contribute to cell death in both hepatocellular 395 carcinoma (HepG2) cells and human cervical carcinoma (Hela) cells, following 
treatment with $\left[\mathrm{C}_{12} \mathrm{MIM}\right] \mathrm{Cl}$ and $\left[\mathrm{C}_{16} \mathrm{MIM}\right] \mathrm{Cl}$ (Wan et al., 2018; Wang et al., 2020;

397 Xia et al., 2018). In work by $\mathrm{Li}$ and co-workers, $\left[\mathrm{C}_{8} \mathrm{MIM}\right] \mathrm{Br}$ induced apoptosis in rat

398 phaeochromocytoma (PC12) cells, triggered by excessive reactive oxygen species 399 (ROS) and mediated by mitochondrial depolarization and permeability transition (Li 400 et al., 2012).

401 Mitochondrial permeability transition has been shown to be affected by $\mathrm{CHX}$ 402 (Negrelo Newton et al., 2004) as well as depletion of cellular ATP content (Hidalgo 403 and Dominguez, 2001). This is also the case for BC which induces ATP depletion in 404 epithelial cells, dephosphorylation of myosin light chain as well as cytoskeletal 405 thinning of cortical actin bundle and reduced cell adhesion (Guo et al., 2007). 406 Toxicity mechanisms of ionic liquids have been reviewed recently (Bubalo et al., 407 2017). Whilst membrane damage remains a key mechanism of toxicity, enzyme 408 inhibition, alterations in cell morphology and oxidative damage were also highlighted 409 as contributing factors.

410 Analysis with CHX has previously shown upregulation of GRP78, BCL-2 and HSP70 411 when assayed by fluorescence microscopy (Faria et al., 2009, 2007). This led us to 412 postulate that ILs and BC may also perturb the endoplasmic reticulum and may 413 contribute through GRP78 induction to apoptosis via the unfolded protein response. 414 As shown in Figure 5, none of the biocides or ILs tested caused a significant 415 alteration to GRP78 expression after $24 \mathrm{~h}$ exposure. This was true even up to $4160.01 \mathrm{mM}$, which in the case of $\mathrm{CHX}, \mathrm{BC}$ and $\left[\mathrm{C}_{14} \mathrm{MIM}\right] \mathrm{Cl}$ are only 60,20 and 40 417 percent viable, or in the case of $0.1 \mathrm{mM}\left[\mathrm{C}_{8} \mathrm{MIM}\right] \mathrm{Cl}, 40$ percent viable. Upregulation 418 of GRP78 in L929 (Faria et al., 2009) may be a cell specific process not observed in 419 HaCat cells, however the apoptotic profile of L929 and HaCat cells is similar as 
measured by annexin V and propidium iodide. This data suggests that GRP78 and the

421 ER play no role in apoptotic cell death for the ILs and biocides tested.

\section{Conclusion}

424 At this point in their evolution, ILs lack substantive cellular mechanistic studies. This 425 study describes a thorough characterization of cell death mechanisms as a result of IL 426 exposure, finding necrosis as the major mechanism of death. While ILs have been 427 shown to be capable of caspase activation and apoptosis, this is a distinct minority of 428 the cell population in comparison to necrosis as signified by LDH leakage. Research 429 on $\mathrm{BC}$ and $\mathrm{CHX}$ point to future areas of investigation, such as studies of reactive 430 oxygen species generation, cytoskeletal changes and cellular metabolism, along with 431 in vivo toxicity studies to assess teratogenicity in particular. Of particular interest is 432 the ability to tune cytotoxicity through anion selection. This suggests unwanted 433 cytotoxicity to the user may in fact be a tuneable property, which can be attenuated 434 without affecting the ability of ILs to perform as biocides. Addressing gaps in 435 knowledge in these areas is of profound importance for the onward development of 436 ILs as consumer grade product constituents, as well as their continued development 437 for safe use in industrial applications.

\section{Acknowledgements:}

440 Funding: We are grateful to the Industrial Advisory Board of QUILL and Invest NI 441 (Proof of Concept Grant No. 27A) for their support of this study. 


\section{References}

444

445

446

447

448

449

450

451

452

453

454

455

456

457

458

459

460

461

462

463

464

465

466

467

468

469

Abruzzo, A., Armenise, N., Bigucci, F., Cerchiara, T., Gösser, M.B., Samorì, C., Galletti, P., Tagliavini, E., Brown, D.M., Johnston, H.J., Fernandes, T.F., Luppi, B., 2017. Surfactants from itaconic acidToxicity to HaCaT keratinocytes in vitro, micellar solubilization, and skin permeation enhancement of hydrocortisone. Int. J. Pharm. 524, 9-15. https://doi.org/10.1016/j.ijpharm.2017.03.056

Berthod, A., Ruiz-Ángel, M.J., Carda-Broch, S., 2018. Recent advances on ionic liquid uses in separation techniques. J. Chromatogr. A 1559, 2-16. https://doi.org/10.1016/j.chroma.2017.09.044

Bhushan, P., Umasankar, Y., Hutcheson, J.D., Bhansali, S., 2019. Toxicity assessment of wearable wound sensor constituents on keratinocytes. Toxicol. Vitr. 58, 170-177. https://doi.org/10.1016/j.tiv.2019.03.034

Brasnu, E., Brignole-Baudouin, F., Riancho, L., Warnet, J.M., Baudouin, C., 2008. Comparative study on the cytotoxic effects of benzalkonium chloride on the Wong-Kilbourne derivative of Chang conjunctival and IOBA-NHC cell lines. Mol. Vis. 14, 394-402.

Bubalo, M.C., Radošević, K., Redovniković, I.R., Slivac, I., Srček, V.G., 2017. Toxicity mechanisms of ionic liquids. Arh. Hig. Rada Toksikol. 68, 171-179. https://doi.org/10.1515/aiht-2017-682979

Busetti, A., Crawford, D.E., Earle, M.J., Gilea, M.A., Gilmore, B.F., Gorman, S.P., Laverty, G., Lowry, A.F., McLaughlin, M., Seddon, K.R., 2010. Antimicrobial and antibiofilm activities of 1alkylquinolinium bromide ionic liquids. Green Chem. 12, 420-425. https://doi.org/10.1039/b919872e

Carson, L., Chau, P.K.W., Earle, M.J., Gilea, M.A., Gilmore, B.F., Gorman, S.P., McCann, M.T., Seddon, K.R., 2009. Antibiofilm activities of 1-alkyl-3-methylimidazolium chloride ionic liquids. Green Chem. 11, 492-497. https://doi.org/10.1039/b821842k

Choi, H., Shin, M.K., Ahn, H.J., Lee, T.R., Son, Y., Kim, K.S., 2018. Irritating effects of sodium lauryl sulfate on human primary keratinocytes at subtoxic levels of exposure. Microsc. Res. Tech. 81, 
Couling, D.J., Bernot, R.J., Docherty, K.M., Dixon, J.N.K., Maginn, E.J., 2006. Assessing the factors responsible for ionic liquid toxicity to aquatic organisms via quantitative structure-property relationship modeling. Green Chem. 8, 82-90. https://doi.org/10.1039/b511333d

Cvjetko Bubalo, M., Hanousek, K., Radošević, K., Gaurina Srček, V., Jakovljević, T., Redovnikovic, R.I., 2014. Imidiazolium based ionic liquids: Effects of different anions and alkyl chains lengths on the barley seedlings. Ecotoxicol. Environ. Saf. 101, 116-123. https://doi.org/10.1016/j.ecoenv.2013.12.022

Dart, J., 2003. Corneal toxicity: The epithelium and stroma in iatrogenic and factitious disease. Eye 17, 886-892. https://doi.org/10.1038/sj.eye.6700576

de Melo, F.C., Bariviera, W., Zanchet, L., de Souza, R.F., de Souza, M.O., 2020. C10MI·CF3SO3: a hydrophobic ionic liquid medium for the production of HMF from sugars avoiding the use of organic solvent. Biomass Convers. Biorefinery 10, 611-618. https://doi.org/10.1007/s13399-01900446-w

Diaz, E., Monsalvo, V.M., Lopez, J., Mena, I.F., Palomar, J., Rodriguez, J.J., Mohedano, A.F., 2018. Assessment the ecotoxicity and inhibition of imidazolium ionic liquids by respiration inhibition assays. Ecotoxicol. Environ. Saf. 162, 29-34. https://doi.org/10.1016/j.ecoenv.2018.06.057

Faria, G., Cardoso, C.R.B., Larson, R.E., Silva, J.S., Rossi, M.A., 2009. Chlorhexidine-induced apoptosis or necrosis in L929 fibroblasts: A role for endoplasmic reticulum stress. Toxicol. Appl. Pharmacol. 234, 256-265. https://doi.org/10.1016/j.taap.2008.10.012

Faria, G., Celes, M.R.N., De Rossi, A., Silva, L.A.B., Silva, J.S., Rossi, M.A., 2007. Evaluation of Chlorhexidine Toxicity Injected in the Paw of Mice and Added to Cultured L929 Fibroblasts. J. Endod. 33, 715-722. https://doi.org/10.1016/j.joen.2006.12.023

Fatemi, M.H., Izadiyan, P., 2011. Cytotoxicity estimation of ionic liquids based on their effective structural features. Chemosphere 84, 553-563. https://doi.org/10.1016/j.chemosphere.2011.04.021 
Ferlin, N., Courty, M., Gatard, S., Spulak, M., Quilty, B., Beadham, I., Ghavre, M., Haiß, A., Kümmerer, K., Gathergood, N., Bouquillon, S., 2013. Biomass derived ionic liquids: Synthesis from natural organic acids, characterization, toxicity, biodegradation and use as solvents for catalytic hydrogenation processes. Tetrahedron 69, 6150-6161. https://doi.org/10.1016/j.tet.2013.05.054

Geerling, G., Daniels, J.T., Dart, J.K.G., Cree, I.A., Khaw, P.T., 2001. Toxicity of natural tear substitutes in a fully defined culture model of human corneal epithelial cells. Investig. Ophthalmol. Vis. Sci. 42, 948-956. https://doi.org/10.1016/S0002-9394(01)01230-2

Giannelli, M., Chellini, F., Margheri, M., Tonelli, P., Tani, A., 2008. Effect of chlorhexidine digluconate on different cell types: A molecular and ultrastructural investigation. Toxicol. Vitr. 22, 308-317. https://doi.org/10.1016/j.tiv.2007.09.012

Gilmore, B.F., Andrews, G.P., Borberly, G., Earle, M.J., Gilea, M.A., Gorman, S.P., Lowry, A.F., McLaughlin, M., Seddon, K.R., 2013. Enhanced antimicrobial activities of 1-alkyl-3-methyl imidazolium ionic liquids based on silver or copper containing anions. New J. Chem. 37, 873876. https://doi.org/10.1039/c3nj40759d

Guo, Y., Satpathy, M., Wilson, G., Srinivas, S.P., 2007. Benzalkonium chloride induces dephosphorylation of myosin light chain in cultured corneal epithelial cells. Investig. Ophthalmol. Vis. Sci. 48, 2001-2008. https://doi.org/10.1167/iovs.06-0613

Hidalgo, E., Dominguez, C., 2001. Mechanisms underlying chlorhexidine-induced cytotoxicity. Toxicol. Vitr. 15, 271-276. https://doi.org/10.1016/S0887-2333(01)00020-0

Holmes, A.M., Lim, J., Studier, H., Roberts, M.S., 2016. Varying the morphology of silver nanoparticles results in differential toxicity against micro-organisms, HaCaT keratinocytes and affects skin deposition. Nanotoxicology 10, 1503-1514. https://doi.org/10.1080/17435390.2016.1236993

Holmes, A.M., Mackenzie, L., Roberts, M.S., 2020. Disposition and measured toxicity of zinc oxide nanoparticles and zinc ions against keratinocytes in cell culture and viable human epidermis. Nanotoxicology 14, 263-274. https://doi.org/10.1080/17435390.2019.1692382 
Kim, H., Nam, K.S., Oh, S., Son, S., Jeon, D., Chan Gye, M., Shin, I., 2019. Toxicological assessment of phthalates and their alternatives using human keratinocytes. Environ. Res. 175, 316-322. https://doi.org/10.1016/j.envres.2019.05.007

Kim, R., Emi, M., Tanabe, K., Murakami, S., 2006. Role of the unfolded protein response in cell death. Apoptosis 11, 5-13. https://doi.org/10.1007/s10495-005-3088-0

Kim, S.S., Kim, J.Y., Lee, N.H., Hyun, C.G., 2008. Antibacterial and anti-inflammatory effects of Jeju medicinal plants against acne-inducing bacteria. J. Gen. Appl. Microbiol. 54, 101-106. https://doi.org/10.2323/jgam.54.101

Lam, P.L., Wong, M.M., Hung, L.K., Yung, L.H., Tang, J.C.O., Lam, K.H., Chung, P.Y., Wong, W.Y., Ho, Y.W., Wong, R.S.M., Gambari, R., Chui, C.H., 2020. Miconazole and terbinafine induced reactive oxygen species accumulation and topical toxicity in human keratinocytes. Drug Chem. Toxicol. 0545. https://doi.org/10.1080/01480545.2020.1778019

Li, X.Y., Jing, C.Q., Lei, W.L., Li, J., Wang, J.J., 2012. Apoptosis caused by imidazolium-based ionic liquids in PC12 cells. Ecotoxicol. Environ. Saf. 83, 102-107. https://doi.org/10.1016/j.ecoenv.2012.06.013

Liu, H., Zhang, X., Chen, C., Du, S., Dong, Y., 2015. Effects of imidazolium chloride ionic liquids and their toxicity to Scenedesmus obliquus. Ecotoxicol. Environ. Saf. 122, 83-90. https://doi.org/10.1016/j.ecoenv.2015.07.010

McLaughlin, M., Earle, M.J., Gîlea, M.A., Gilmore, B.F., Gorman, S.P., Seddon, K.R., 2011. Cytotoxicity of 1-alkylquinolinium bromide ionic liquids in murine fibroblast NIH 3T3 cells. Green Chem. 13, 2794-2800. https://doi.org/10.1039/c0gc00813c

Megaw, J., Busetti, A., Gilmore, B.F., 2013. Isolation and Characterisation of 1-Alkyl-3Methylimidazolium Chloride Ionic Liquid-Tolerant and Biodegrading Marine Bacteria. PLoS One 8, e60806. https://doi.org/10.1371/journal.pone.0060806

Nędzi, M., Latała, A., Nichthauser, J., Stepnowski, P., 2013. Bioaccumulation of 1-butyl-3methylimidazolium chloride ionic liquid in a simple marine trophic chain. Oceanol. Hydrobiol. Stud. 42, 149-154. https://doi.org/10.2478/s13545-013-0068-9 
Negrelo Newton, A.P., Cadena, S.M.S.C., Merlin Rocha, M.E., Skäre Carnieri, E.G., Martinelli De Oliveira, M.B., 2004. New data on biological effects of chlorhexidine: Fe2+ induced lipid peroxidation and mitochondrial permeability transition. Toxicol. Lett. 151, 407-416. https://doi.org/10.1016/j.toxlet.2004.02.013

Orlowski, P., Soliwoda, K., Tomaszewska, E., Bien, K., Fruba, A., Gniadek, M., Labedz, O., Nowak, Z., Celichowski, G., Grobelny, J., Krzyzowska, M., 2016. Toxicity of tannic acid-modified silver nanoparticles in keratinocytes: Potential for immunomodulatory applications. Toxicol. Vitr. 35, 43-54. https://doi.org/10.1016/j.tiv.2016.05.009

Pasupuleti, M., Schmidtchen, A., Chalupka, A., Ringstad, L., Malmsten, M., 2009. End-tagging of ultra-short antimicrobial peptides by W/F stretches to facilitate bacterial killing. PLoS One 4, e5285. https://doi.org/10.1371/journal.pone.0005285

Pendleton, J.N., Gilmore, B.F., 2015. The antimicrobial potential of ionic liquids: A source of chemical diversity for infection and biofilm control. Int. J. Antimicrob. Agents 46, 131-139. https://doi.org/10.1016/j.ijantimicag.2015.02.016

Pernak, J., Sobaszkiewicz, K., Foksowicz-Flaczyk, J., 2004. Ionic liquids with symmetrical dialkoxymethyl-substituted imidazolium cations. Chem. - A Eur. J. 10, 3479-3485. https://doi.org/10.1002/chem.200400075

Pernak, J., Sobaszkiewicz, K., Mirska, I., 2003. Anti-microbial activities of ionic liquids. Green Chem. 5, 52-56. https://doi.org/10.1039/b207543c

Piotrowska, A., Syguda, A., Wyrwas, B., Chrzanowski, L., Luckenbach, T., Heipieper, H.J., 2018. Effects of ammonium-based ionic liquids and 2,4-dichlorophenol on the phospholipid fatty acid composition of zebrafish embryos. PLoS One 13, 1-11. https://doi.org/10.1371/journal.pone.0190779

Poulter, N., Munoz-Berbel, X., Johnson, A.L., Dowling, A.J., Waterfield, N., Jenkins, A.T.A., 2009. An organo-silver compound that shows antimicrobial activity against Pseudomonas aeruginosa as a monomer and plasma deposited film. Chem. Commun. 2009, 7312-7314. https://doi.org/10.1039/b915467a 
Pretti, C., Chiappe, C., Pieraccini, D., Gregori, M., Abramo, F., Monni, G., Intorre, L., 2006. Acute toxicity of ionic liquids to the zebrafish (Danio rerio). Green Chem. 8, 238-240. https://doi.org/10.1039/b511554j

Pulingam, T., Thong, K.L., Appaturi, J.N., Nordin, N.I., Dinshaw, I.J., Lai, C.W., Leo, B.F., 2020. Synergistic antibacterial actions of graphene oxide and antibiotics towards bacteria and the toxicological effects of graphene oxide on human epidermal keratinocytes. Eur. J. Pharm. Sci. 142, 105087. https://doi.org/10.1016/j.ejps.2019.105087

Radošević, K., Cvjetko, M., Kopjar, N., Novak, R., Dumić, J., Srček, V.G., 2013. In vitro cytotoxicity assessment of imidazolium ionic liquids: Biological effects in fish Channel Catfish Ovary (CCO) cell line. Ecotoxicol. Environ. Saf. 92, 112-118. https://doi.org/10.1016/j.ecoenv.2013.03.002

Samorì, C., Pasteris, A., Galletti, P., Tagliavini, E., 2007. Acute toxicity of oxygenated and nonoxygenated imidazolium-based ionic liquids to Daphnia magna and Vibrio fischeri. Environ. Toxicol. Chem. 26, 2379-2382. https://doi.org/10.1897/07-066R2.1

Sintra, T.E., Nasirpour, M., Siopa, F., Rosatella, A.A., Gonçalves, F., Coutinho, J.A.P., Afonso, C.A.M., Ventura, S.P.M., 2017. Ecotoxicological evaluation of magnetic ionic liquids. Ecotoxicol. Environ. Saf. 143, 315-321. https://doi.org/10.1016/j.ecoenv.2017.05.034

Sugita, Y., Takao, K., Uesawa, Y., Sakagami, H., 2017. Search for new type of anticancer drugs with high tumor specificity and less keratinocyte toxicity. Anticancer Res. 37, 5919-5924. https://doi.org/10.21873/anticanres.12038

Sydow, M., Owsianiak, M., Framski, G., Woźniak-Karczewska, M., Piotrowska-Cyplik, A., Ławniczak, Ł., Szulc, A., Zgoła-Grześkowiak, A., Heipieper, H.J., Chrzanowski, Ł., 2018. Biodiversity of soil bacteria exposed to sub-lethal concentrations of phosphonium-based ionic liquids: Effects of toxicity and biodegradation. Ecotoxicol. Environ. Saf. 147, 157-164. https://doi.org/10.1016/j.ecoenv.2017.08.026

Thamke, V.R., Chaudhari, A.U., Tapase, S.R., Paul, D., Kodam, K.M., 2019. In vitro toxicological evaluation of ionic liquids and development of effective bioremediation process for their removal. Environ. Pollut. 250, 567-577. https://doi.org/10.1016/j.envpol.2019.04.043 
Venkata Nancharaiah, Y., Reddy, G.K.K., Lalithamanasa, P., Venugopalan, V.P., 2012. The ionic liquid 1-alkyl-3-methylimidazolium demonstrates comparable antimicrobial and antibiofilm behavior to a cationic surfactant. Biofouling 28, 1141-1149. https://doi.org/10.1080/08927014.2012.736966

Wan, R., Xia, X., Wang, P., Huo, W., Dong, H., Chang, Z., 2018. Toxicity of imidazoles ionic liquid [C16mim]Cl to HepG2 cells. Toxicol. Vitr. 52, 1-7. https://doi.org/10.1016/j.tiv.2018.05.013

Wang, P., Wan, R., Huo, W., Dong, H., Chang, Z., Xia, X., 2020. Cytotoxicity, genotoxicity, oxidative stress, and apoptosis in HepG2 cells induced by the imidazole ionic liquid 1-dodecyl-3methylimidazolium chloride. Environ. Toxicol. 665-672. https://doi.org/10.1002/tox.22901

Wells, A.S., Coombe, V.T., 2006. On the freshwater ecotoxicity and biodegradation properties of some common ionic liquids. Org. Process Res. Dev. 10, 794-798. https://doi.org/10.1021/op060048i

Wilhelm, K.P., Böttjer, B., Siegers, C.P., 2001. Quantitative assessment of primary skin irritants in vitro in a cytotoxicity model: Comparison with in vivo human irritation tests. Br. J. Dermatol. 145, 709-715. https://doi.org/10.1046/j.1365-2133.2001.04497.x

Xia, X., Wan, R., Wang, P., Huo, W., Dong, H., Du, Q., 2018. Toxicity of imidazoles ionic liquid [C16mim]Cl to Hela cells. Ecotoxicol. Environ. Saf. 162, 408-414. https://doi.org/10.1016/j.ecoenv.2018.07.022

Yu, J., Zhang, S., Dai, Y., Lu, X., Lei, Q., Fang, W., 2016. Antimicrobial activity and cytotoxicity of piperazinium- and guanidinium-based ionic liquids. J. Hazard. Mater. 307, 73-81. https://doi.org/10.1016/j.jhazmat.2015.12.028

Yuan, Y.G., Peng, Q.L., Gurunathan, S., 2017. Effects of silver nanoparticles on multiple drugresistant strains of Staphylococcus aureus and Pseudomonas aeruginosa from mastitis-infected goats: An alternative approach for antimicrobial therapy. Int. J. Mol. Sci. 18, 569. https://doi.org/10.3390/ijms18030569 